\title{
Bochkarev S.A.
}

\section{Difficulty Understanding the Being of Criminal Law}

\begin{abstract}
The article attempts to bridge the gap between philosophic and legal experience and theory of criminal law on cognition of the nature of this law and highlights the complications of their rapprochement. The article raises the problem of comparability and synthesis of these two lines of legal thought. In this respect, the research reviews the narrative of philosophic and legal thoughts in the sphere of cognition of the Being. The author stresses the role of modernity in interpreting the Mode and the Being of criminal law as a reason for reflection and as a timely object of understanding the philosophic and legal thought. In general, thoughts apprehend themselves and understand their self-sufficiency. The same is with the so called modern thought. Whatever its dreadful state, it remains a means of social linkage. Each of these thoughts finally constructs its own Babylon. Mutual misunderstanding is then referred to the imperfection of its nature or prejudices of its subjects. However the stumbling point is in the level of aloofness of thoughts from each other and from a man in general. They no longer weigh and counterbalance, but divide it. In their interpretation the subject seizes to possess its own being.
\end{abstract}

Keywords: criminal law, the due, being, philosophic thought, sense, legal thought, nature, existence, the real, ontological thought.

$\mathrm{T}$ he research problem of the Being of criminal law is both ambitious and utopian. Its utmost cognition deems almost irreal, as is suggested by the experience of the world philosophic thought. However, with many philosophic problems resolved, the research fields of the criminal law philosophy remains void of acceptable solutions to the existing issues, as major philosophic problems in this domain have not been resolved.

For many centuries, the world philosophic narrative has not produced certainty in ontological thought. Advocates of the founding fathers (as well as the latter ones themselves) of all known philosophic systems prove the subjectivity and incompleteness. As stated by Russian philosopher V.A.Kanke, "Theories recognized as true...sooner or later were showed their incompleteness...As it is the case with any theory, as it emerges, reaches its culmination, and then is refuted." . Here, as Ojzermann T.I. believes, the case lies in the ambivalence of the philosophic thought itself, as every beginning of it serves as its end and vice versa. Dialectical contradictions is one of its features. Uncertainty of everything associated with this thought is recognized as its benefit and evidence of the richness of content, eloquence and variety.

In Ojzermann's opinion, this situation is characteristic of the study of philosophy in general: "One can

1 Kanke V.A. Filosofija. Moscow, 2000, p. 112-113. scrutinize any philosophic term only to discover its internal ambivalence"2. It is a common thing in the study of philosophy to see that almost every metaphysical system is a negation of the previous system and often a negation of the former sense of the metaphysics as well $^{3}$. Controversy of philosophic thoughts is considered the only objective certainty, with two-sidedness being a norm. "permanent confrontation of philosophic studies creates an internal rhythm of development of philosophic trends"4.

Multiplicity in understanding of the Law is also a common and long-term phenomenon. Since ancient times, philosophers of law have shared the opinion of Alkmaeon of Croton and other Pythagoreans that polarities are the essence of all things. In this respect, pluralism can be attributed as one of features of legal thought. The spheres of the Morale and Morality generally concur with philosophic thought, especially in the areas of generating Sense. A complicated process of comprehension and cognition of law necessitates elimination of controversies. This process, as Matuzov N.I believes, presupposes discovering and reasoning of

\footnotetext{
2 Ojzermann T.I., Ambivalentnost philosofii, Moscow, 2011, p.8.

3 See more in Ojzermann T.I. Metaphilosophija. Teorija istoriko-filosofskogo processa, Moscow, 2009, p. 320.

4 See more in Ojzermann T.I. Metaphilosophija. Teorija istoriko-filosofskogo processa, Moscow, 2009, p. 309.
} 
legal terms both objectively and subjectively ${ }^{5}$, as their alignment in criminal and legal dimensions is multifaceted, however comprehensive. "No obligatory action can be a unique value" - stated Mur D. ${ }^{6}$ Also, "to show that an action is an obligation, it is necessary to know the other conditions that together with this action shape and determine its consequences..."7.

The sphere of the subjective is a major part of the essence of criminal law. The meaning of purely internal conditions of a human soul, various realms of a human soul's world: thoughts, hope and aspirations, axiologies, motivations, moods of mind and etc., naturally prevails over any external factor. They are a priority. No criminal and legal decision may be made without evaluation of the subjective. This distinguishes them from decisions made in other spheres of law. The institute of the Guilt is the cornerstone of all decisions in criminal law. When components of crime - corpus delicti - are considered, objective features of action are aligned with subjective ones. The results of this association determine and discover the sense of the whole criminal-legal intention.

However, a lawyer may deem instability of philosophic thought dubious, as his viewpoint is not able to accommodate the whole variety of philosophic domains. He would follow the law enactment process format and this become overloaded with ontological uncertainty. Criminalists would doubt that philosophy and its questions of the Real with all similarities between philosophic, criminal, and legal thoughts and uniformity of their theoretical and practical implementations can claim the status of solid fundament for the whole criminal and legal system of thought. These will show the evident difference between system of the theoretical and practical and the philosophic.

As Russian researcher Alpatov A.A. believes, the review of legal concepts reveals adherence of Law as a science towards a single and universal definition of law. To this moment, the aspiration to produce such a definition based on holistic theoretical basis is still relevant $^{8}$. Even those advocating multiplicity of interpretations of law avoid relativism. They use means of classification and unification of visions on law.

This aspiration is explainable. It stems from the normative nature of law. Upon scrutinizing criminal

\footnotetext{
5 Matuzov N.I. Aktualnije problem teorii prava. Saratov, 2003, p. 90.

6 Mur D. Principi etiki. Moscow, 1924, p. 207-208.

7 Mur D. Principi etiki. Moscow, 1924, p. 234-235.

8 See Alpatov A.A. Retrospektiva I sovremennoye sostoyanije vzgliadov na prirodu prava/Pravo, - Higher School of Economics Russia, 2011, № 3-4, p.5.
}

and legal understanding one can see that it is subjected to the aim of producing the imperative as a single possible way out of criminal oblivion with no alternatives. Ambivalence and even more, variety of understandings in criminal and legal sphere are not welcome. The idea of this law puts it over any hesitations in criminal intents. Its goal as a symbolic power is focused in attesting the unassailable nature of the values defended by the criminal law and the senselessness of any conflicts and contradictions that may be produced by them ${ }^{9}$.

In this respects, criminalists shall always be right in their doubts. They would not reject the fact that philosophic and legal analogies, scrutinized here, are true and convincing. However, there is one flaw they would see in these: particularities of legal thought are shadowed by their similarities. Characteristic features of these thoughts are blurred, which creates another risk, warning any researcher not to forfeit resolution of real problems of law for the analysis of philosophic dilemmas.

Still, there is a difference between them, which should be taken into account. It originates from the point that criminal and legal thought has a different assignment in reality and thus it possesses a different level of freedom and responsibility before mankind and society. If philosophy can allow itself to diminish everything within its borders to the ground, then law is invalid of such freedom. Law, and even more - criminal law - lacks authority for revolution within the reach of its competencies. Almost in all cases, at all stages of human history the prime fate of law has been the provision of evolution. It is not uncommon that philosophers have always assessed the right of law to revolutionize. Lawyers rarely attempted it. American philosopher Payne T. writes: "When all other rights are violated, right to rise against becomes indisputable". German historian and literature researcher Mommzen T. said, that "When government fails to govern, it stops being legal, and the one possessing power has the right to oust it".

Definitely, legal thought has had moments of radicalism. At times, it became its own opposite or simply the show-case for tyranny, when it took as example or deemed acceptable the thought revealed by the student and follower of J. - J.Rousseau. manifesting his vision on his teacher and his legacy, L.Feuchtwanger wrote: "True to your study, we shall take the crow-bar and shall ruin the old to the bottom and shall collect the stones to build a new building, never revealed by the

\footnotetext{
9 See more in Bochkarev S.A. Ideja ugolovnogo prava i yeyo filosofskoe iamerenije/Aktualnije problem rossijskogo prava, 2012, № 1, pp. 206-222.
} 


\section{Bochkarev S.A.}

world before. It may become that me and my kind shall have to pay for our deed by the utmost poverty or even premature death. I shall not be afraid of it." ${ }^{10}$

Criminal and legal thought may not avail itself of such luxury. Philosophic thought, as shown on examples above, is more free and even arbitrary. It attests to many freedoms as it is not weightened by the practical side of its implementation. In this format, philosophic thought seems similar to political thought, which is also open to wide variability, however due to it being pressed over by the practical attributiveness. Russian researcher Menshikov M.O. reminds us that "the Power of Authority lies not in intent, but in implementation"11.

Both for philosophic and political thoughts no unbearable borders or barriers may be seen. Both efficiently avoid or adapt for their purposes various moral boundaries and other limitations of humanistic kind. History shows examples of when a desire to fit certain philosophic ideas or political beliefs led to demolition and even human casualties. History has not been deemed as relevant and was used as a token of exchange when needed.

The idea of law, conservative in all senses, balances between the philosophic and the political thought. On such foreground law appears limited, as it cannot divide and rule. Ambivalence for law as constant conflict is an initial and expendable material. Controversy is not the aim of law, nor is it its own fundament. For legal practice, any statement or sustaining of negation as aim in its own right is similar to self-destruction.

Criminal law defies wide-scale argument nor in legal thought, nor in the very thought over right to live, which stands outside the civil law framework. The notion of the contrary is not the idea of law itself. It is merely a slight thought of a crime, as noted in world literature, i.e. by Dostoevsky F.M. However, contemporary criminal law lacks such level and scale of thinking. Criminal justice, as believed by those engaged in this sphere, fulfills the goal of punishing by any means. It pays no attention to costs borne by the country, nor to negative consequences in the area of social structure of society ${ }^{12}$. Criminal and legal thought does not apprehend the fact that it is called upon to serve the ideals of

\footnotetext{
10 Feuchtwanger L. Mudrost chudaka, ili smert I probrajhenije Jan-Jaka Rousseau. Moscow, 1965, c 137-138.

11 Menshikov M.O. Power as right/ Great Russian Idea/edited by Trofimova V.B.//supervised by Platonov O.A. Moscow, Institute of Russian Civilization, 2012, volume 1, p. 131.

12 See more in Babakov A.M., Radchenko V.I. Modernizatsiya ugolovnogo zakonodatelstva: srok za pribil//Ugolovnaya politika v sfere ekonomiki: ekspertnije otsenki. Moscow, Fond "Liberalnaya missija", 2011, pp. 46-47.
}

conservatism, the end to which it should correspond. Criminal justice should serve as a bridge between the past and the present narrative and developments without allowing any breaches in it nor internally nor externally, as these bridges are an integral part of ontological fundamentals of living. It should neither lose its depth and become superficial, - the shelter of revolutionaries, as believed by Berdiaev N.A.

A supreme task of legal thought is to maintain an acceptable level of peace in society by blocking or preventing of what Ojzermann called the benefit of philosophic thought. The core aim of criminal and leval thought is to offer means of protecting its subjects from tragism, which, as stated by Berdiaev N.A., "stems from the clash between the end and the endless, temporary and eternal, from discrepancy between man as a spiritual being and man as a natural being living in the natural world"13.

Above I developed the rational side of the research problem. Judging the arguments above, the rationale of it does not attest for attempts to scrutinize the being of criminal law with methods of philosophers. It is assumed that the ontological assessment of this area of criminal law is not only prone to errors, but at times even doubtful and not capable of leading towards successful results. There is no certainty in that philosophic thought may serve a guiding star in the real domain. There are slight differencies between them in aims and means of attaining them, levels of freedom and responsibility. Cautiousness of legal thought is also sustained by the examples from history of philosophy, in which, as Heidegger M. outlined, there were long-term periods when the issue of the sense of living was claimed irrelevant, and the Real itself was recognized a most wide and senseless notion. ${ }^{14}$ in other words, arguments of the researched types of thought demonstrates the formal and the thematic barriers between them, as well as the inability at current stage of development to unite efforts for learning the Real in general and the criminal law in particular.

The Irrational side of the research question does not spare the doubts above, as it may seem at the first glance. It represents a habitual and unequipped consciousness of a man, who also has his own thought (however non-philosophic and non-legal it may be). Such thought is always existential, not necessarily subjected to formal logical structures and almost in all cases it is burdened by the concrete historical experience.

\footnotetext{
13 Berdiaev N.A. Sudba Rossii. Moscow, 1990, pp. 328-329.

14 Heidegger M. Bitie I vremya/translated from german by Bibikhina V.V. Moscow, Akademichesky prospect, 2011, p. 2.
} 
It applies its own cultural and historic experience, from which it takes power and reasons to obey or counteract its own rational side. It may also produce an intuitive prejudice towards apprehension or non-apprehension of the living. These prejudices are to be taken into account, though they may originate from historic or spontaneous fears, believed Heidegger M. They are a tested source of the so-called pretextual knowledge, which axiomatically knows the living. This axiomatic knowledge produces the issue of the sense of living and the tendency to assess it. Humankind does not see the horizon, which may lead us towards apprehending the living, though it is already represented in each one of us in its common and vague form ${ }^{15}$.

It is primarily the intuitive feelings that today serve as a source of conclusion-making on the issues of the unprecedented crisis in law in $21^{\text {st }}$ century. Various researchers have expressed their concerns on this issue worldwide. Authors categorically and emotionally argue their concerns, driven by the expectations of aggravation of situation in the sphere of law and the onset of consequences that are negative for its subjects. Berman G.G. called these emotions intuitive feelings. Although he deemed them non-scientific, he attached great importance to them as a means of proving the thesis. On the example of analysis of history of the western tradition of law Berman he convinced himself that reality lacks objective evidence, which shows the depressive state of law. He wrote: "I can only state what I feel : that a man of West is now centered in the whirlpool of an unprecedented crisis of legal values and legal thought"16.

Famous Russian hisotorian of law Korkunov N.M. also noted the reasoning in such prejudices, which affected the development of legal thought. In his "History of philosophy of law" he showed a negative example of influence of various religious beliefs on his followers. In particular, he saw the reasons of absence of history of philosophy studies at all faculties of natural science as a result of popular beliefs that philosophic notions "shall give nothing to us in the sense of better understanding of theory of numbers of law of celestial mechanics" ${ }^{17}$. These stereotypes would have fallen into oblivion.

Nonetheless, the prejudice noted above are in act at present as well. Permiakov Y.E. rightfully attracts attention to the fact that Russian scientists of law prefer

15 Heidegger M. Bitie I vremya/translated from german by Bibikhina V.V. Moscow, Akademichesky prospect, 2011, p. 5.

16 Berman G.G. Zapadnaya tradicija prava: epokha formirovanija. Moscow, 1994, p. 13.

17 Korkunov N.M. Istorija filosofii prava. 7th Edition, Moscow, Krasand Publishers, 2011, p. 2. to abstain from assessing "the eternal questions"18. This is highly relevant for the particular areas of law. Criminal law is no exception to that. It is possible that criminalists are still under influence of the likewise assumptions. They can altogether believe that metaphysical dimension of criminal law is unable to assist them in their search of best assessment of theory of crime or the study of punishment. Not every professional can find inner strengths to recognize that. Meanwhile the research process shows that criminal law science does not show interest in "profound" topics. Usually only solitary papers are dedicated to these topics, and thus majority of them stays out of prime attention of researchers.

In the researched case the routine and prejudice based on it also point at inapprehensiveness of the living and even at the irrelevance of such issue. J. - P.Sartre explained this by the essence of the modern thought, which has developed widely. As Goethe's Zeitgeist determines the essence of a given time, so does the modern thought. Russian researcher Chestnov I.L. maintains that this thought is equal to a particular stage of development of a given society ${ }^{19}$. It guides society in the world of ideas. As illustrated by the spiritual and moral writings, today this thought claims its solid conviction that "nowadays culture is modernized and produces the best types of culture"20. American psychologist E.Fromm expressed the idea that a man's mind is guided by the idea of him building a material world, the reality of which oversheds dreams and images of fairy tales and utopias. "Today, first time for the whole history, a man may feel how an idea of uniformity of humankind and the conquest of nature for the goodness of a man is not a mere dream, but a real opportunity"21. A thought no longer needs ontology to apprehend its own grounds at the utmost levels of living. This thought proclaimed all its surroundings as its habitat and now it dictates its consumers visions of the Real as of a series of events that ostensibly demonstrate $i^{22}$.

\footnotetext{
18 Permiakov Y.E. Vozvrashenije k metafizike v nauchnom poznanii prava//Pravo I obschestvo v epokhu peremen, Moscow, 2008, p.9.

19 See Chestnov I.L. Obsheje I osobennoje v prave//Gosudarstvo I pravo na rubejhe vekov. Saint-Petersberg, 2000, p.33.

20 Velikie russkie starzi: jhitie, chudesa, dukhovnije nastavlenija. Moscow, 2000, c.670.

${ }^{21}$ Fromm E. Chelovek dlia sebya. Revolutsija nadejhdi. Imet ili bit (translated from english and german/Erich Fromm, Moscow, AST publishers, 2007, p.16).

22 See Sartre J.-P. Bitie I nichto. Opit fenomenologicheskoj ontologii (translated from french)/Jean-Paul Sartre, Moscow, AST publishers: ASTREL, 2012, p.31.
} 


\section{Bochkarev S.A.}

As phenomenologists claim, by trusting such a thought researchers aspired to clear several dualisms burdening philosophy. However, by doing so they created a trichotomy. And produced a system of views based on routine experience, in which no event exhibits itself in a satisfactory manner. Each of them is a continuation of the previous one and the beginning of the following one. Events do not have nor their own nature, nor they possess solely the origins of the event itself. "All of them refer to other events and none of them can be claimed preferable against the other"23. A continuous line of routine circumstances has become a subject of legal assessment. No single action is sufficient to disclose its essence. "None of them points at anything left behind... The visionable refers to a line of its illustrations, and not to the clandestine reality that would absorb the Real of the living"24, - wrote Sartre.

The enforcers of law cherished this philosophy of life. With legal paradigms on the scourge, law enforcers applied effortless and seemingly true, practical means that result from the environment. Earlier a justification for this approach was provided by the school of natural realism, followers of which, possibly accidentally, became its enforcers. Sellars believed that their choice was humane. A common man, who only perceives and react to physical influences by limited means was proclaimed the basis of natural realism. "He lives among perceivable things, adapts to them and makes them his instruments" 25 . This man recognizes that his calling towards his environment shall change nothing, believes F.Rauch ${ }^{26}$.

The methodology discussed above deems relevant as its source is apprehendable for all researchers and is easily tracked. A naturalistic view on the development of the world has shaped a vision on its realism and selfdetermination. Naturalists view the environment not only as a general subject of every man's perception, but also as a form and means of independent being of nature. Eternal routine, narrow-mindedness of human perception prove their independence and autonomy.

Logical ties and values are left in the backyard of naturalism, where Darwin's theory explains them with

\footnotetext{
23 See Sartre J. - P. Bitie I nichto. Opit fenomenologicheskoj ontologii (translated from french)/Jean-Paul Sartre, Moscow, AST publishers: ASTREL, 2012, p.31.

24 See Sartre J. - P. Bitie I nichto. Opit fenomenologicheskoj ontologii (translated from french)/Jean-Paul Sartre, Moscow, AST publishers: ASTREL, 2012, p.32.

25 Sellars R.W. The essentials of Philosophy. University of Michigan. The Macmillan Company. 1917, p.18.

26 Rauh F. Essai sur le fondement metaphysique de la morale. Paris, 1891, p.11.
}

means of natural evolution. Theory of knowledge, as a result, is substituted by the theory of perception. In naturalism, laws of morale explain the laws of things. A man is deemed moral if he acts in correspondence with reality. An honest man shall be the man who follows the evolution of the Universe. Repentance is understood a discrepancy between individual aspiration and social instinct ${ }^{27}$. Thoughts of freedom are limited by the ability of a man to live, which is determined at the level of self-conscience ${ }^{28}$. Advocates of naturalism use the describe fundamentals to derive norms of law. The starting point for such act is the experience of daily routine and common sense.

As for theoretical and practical study of law, it is important to stress here that it follows the described way of development. The domain of legal studies as such has found a way out of societal problems of transformation period by attesting to its environment directly as a source of its comprehension. This tendency has been found in general law theory as well. It has been qualified as a demonstration of positivism, oriented at purely empirical matters, and at general relativism as a dominating trend of the modern world.

As viewed by Russian law scientist Graphsky V.G., this dominating trend has led to the loss of a "old-fashioned skill to separate the eternal from the passing"29. Another Russian lawyer, Permiakov Y.Y., pointed at the loss of value of the status of law, by which almost any legal act is attributed to nowadays: "Anything stemming from the authority is now concerned to be law, and anything aspiring to domination is concerned to be power"30. Overall, as noted by Berman G.J., the whole tradition of law is challenged - with not only the liberal ideas of the last two decades, but the whole fundament of justice is defied, though it has been developing since 11-12 centuries $^{31}$. Faith in Law is defied, as is its comprehensiveness $^{32}$. A general need of society in Law is diminished.

However, not all legal domains share this understanding of law. Criminal and legal thought, for example, has not yet shared the vision of law being

$27 \quad$ Ibid. p. 8-9, 12-13.

28 Ibid. p. 70-72.

29 Pravo I obschestvo v epokhu peremen. Moscow, 2008, p.3.

30 Permiakov Y.Y. Vozvraschenije $\mathrm{k}$ metafizike $\mathrm{v}$ nauchnom poznanii prava//Pravo I obschestvo v epokhu peremen. Moscow, 2008, p.11.

31 See more in: Berman G.J. Zapadnaya tradicija prava: epokha formirovanija. Moscow, 1994, p.13.

32 See more in: Berman G.J. Vera I zakon: primirenije prava I religii. Moscow, 1999. 
a hostage of positivism. Moreover, moderators of this line of thought went further than substituting the real by the existing. They came to equate ontologically founded notions, produced by Sartre, with everyday routine. Criminal law came to be understood and exploited not as if it were rooted in society, but as an attribute of political or economic power, not as a civilized condition and a balanced fundament for the coexistence of the system of "the individual, society and state", but as a police-type opportunity to exhibit authority by the incumbent. Basing on the statistics of the bills introduced to Parliament, bills reviewed and bills passed into law, popular representation has limited access to power. The level of societal involvement in implementation of legal initiatives in the sphere of criminal law and the value of its contribution are minimal. This sphere of legislation is perceived as a zone of predominant expression of will of the guarantor of the Constitution. He alone possesses the non-verbal initiative of reforming both criminal law and the legal system overall.

In criminal legal understanding the former visions on law and its purpose are gradually diminishing. Judges, attorneys and investigators widen the sphere of application of criminal and legal norms for the purpose of educating their subjects through revision on previous dogmas. Non-textual principles are easily overcome by claiming them obsolete and not provided by the law. Arguments on their non-correspondence with requirements of time are enough for formulating alternative norms that do not conclude directly from the provisions of criminal law. Their basis is usually the result of grassroot experience, that are concluded as more valuable, than abstract general legal categories, and are sufficient for producing the notions that are deficient in trial decision-making. Cases of application of nonlegal terms in formulating the charges at court are now numerous. Also, many cases of attempting to call the consequences of convicted crime "with simple names" are abundant. Lots of cases are reviewed on an "situational" analysis, when no analysis in fact is made to investigate the crime.

Characteristic features of the explained above influenced criminal linguistics as well. Today criminallegal language used at courts loses its functionality and discipline with the development of frequency of use of normatively undetermined and consciensciously hardly distinguishable criteria (adequacy, effectiveness, normality, applicability, benefit, optimum and etc.). Unfortunately, as noted by Russian researcher of law Jhalinsky A.E., a narrative and linguistic approach towards investigating cases of utmost criminal impor- tance for the whole country is now rooted ${ }^{33}$. The major category of disciplines of the criminal cycle - criminality as an absolute evil - is hidden by theorists under a labile notion of a deviant behavior. A widening circle of law interpreters has also cast its negative influence on the multiplicity of "junk" words in the criminal and legal vocabulary. Each of them persists in himself being the utmost authority. Here, the case is not with the principle of competitiveness at court. Elements of unofficial debate are woven into the principles of action of subjects of the prosecution by the legislation. Alongside, the role of disciplinary structures in the system of justice, which at the preliminary hearings help to maintain a universal application of law, is minimized.

As a result, criminal process is overloaded with massive texts of habitual speech, with hermeneutics supporting this. It was expected earlier, that hermeneutics would demonstrate means of extracting general definitions from routinely understood notions with the help of grammatical, lexical and other philological practices. However, no miracle was produced. Hermeneutics was challenged with the problems of understanding law. Requirements of the former are not perceived by the subjects of law without depicting its ontological grounds. It is incapable to derive the conditions, that would be axiomatic for legislation and application of law by itself. It needs ontology, which today undergoes a testing process on the level of different researches.

Values of the Real have forfeited their predominance for the pure interest under the pressure of the temporary. The problem of justice no longer occupies the agenda. It has exhausted itself by questioning formal equality, which in its modern interpretation does not have any axiological context. Today researchers presuppose that all are equal before law and trial. No attention is attracted to the other side. Many fail to see that the law and those who uphold and implement it, in their turn, not always treat everyone as equals. The extraction of the only truth in criminal cases investigation is no longer an aim nor the purpose of prosecution. Instead, issues of alikeness, competitiveness, sufficiency and determination are on top agenda now. The object of application of law today is, in Kun T.'s wording, a puzzle. As Popper K. wrote, there are no fundamental problems underlying them ${ }^{34}$.

The science of criminal law is unable to assist the law enforcer, as it fails to identify itself. Former limits

\footnotetext{
33 Jhalinsky A.E. Ugolovnoe pravo v ojhidanii peremen: teoretiko-instrumentalnij analiz. Moscow, 2008, p.5.

34 See Popper K. Normalnaya nauka I opasnosti, sviazannie s nej//Filosofija nauki, 1997, № 3, p.51.
} 


\section{Bochkarev S.A.}

of its object are swept away by practice. Imperative is no longer a preferable quality of the criminal and legal method. Representatives of contemporary science are not capable to describe with certainty the new parameters of the researched area of law. By offering to fully join the categorical apparatus of other branches of law, they in fact do not offer anything individual in the study of criminal law. A possibility to use institutions, terms and definitions of other areas of legislation in the senses in which they are understood in their original areas, is growing popular ${ }^{35}$.

One may view the described situation as grave. However, with prejudice and routine as sources of the Real modern thought in first instance forces us to believe truths of the Heraclytian thought on that all sensitive things are in permanent motion and there is no knowledge of these things. It is the modern thought, which, as claimed by Sartre, easily and almost effortlessly returns its subscribers to the Reality as its opposition. Through its antithesis modern thought points at the superficiality as an irredeemable and neoontological characteristics of the way of development of the modern criminal and legal thought. Its own lack of ideas and speediness attract attention to the safe definition of the issues of the Real, the resolution of which can free this thought from the preponderance of the variety and unlimitness of the whole existent in reality. Whilst the Real is in abundance today, it leaves no space for the material substance (eternal and obligatory). Thoughts primarily are devoted to the events of the everyday life; in the abundance of them their moderators try to see the material substance.

Positivists may at this point justify the choice of specialists towards routine experience as a true source of the whole worldview. They can claim that this choice was a pragmatic one and also an intimidated decision of society, which was forced to act in conditions of one system losing its significance and another not having obtained any yet. The philosophy of the environment has proved expectations of law researchers. It has served, and, as it seems, will continue to serve as a profound basis for resolution of everyday problems of transitional societies. Existencial dimension of routine, as Kasavin I.T. and Schevelev S.P. believed, successfully incorporates all ambiguous situations and transforms them into a source of courage and patience ${ }^{36}$.

\footnotetext{
35 Koncepcija modernizazii ugolovnogo zakonodatelstva v ekonomicheskoj sfere. Moscow, 2010, p.49.

36 See more in: Kasavin I.T., Schevelev S.P. Analiz povsednevnosti. Moscow, 2004, p.14.
}

Accounting for the views expressed by Empedocle, Leukippos and Demokritos, one may even assume that the approach choosen by the the law scientists has its grounds, as it can attest for a classical philosophic fundament. As these scientists believe, empirical experience is a material which in reality is the source and reason of all other things. All other events and their qualities derive from its conditions. Being a general substance, this material does not emerge nor collapse - it is eternal. Parts of this materia may compose any other substance, including the one of criminal and legal kind.

However, everyday routine and the thought of it are strong among positivists. Firstly, as Pierre Bourdieu noted, they can not see and obtain the logics that is expressed in their practices ${ }^{37}$. Logics in general and the logic of law does not derive from practical experience, but is only proved or disapproved by it. Secondly, in case with material, as Aristoteles believed, "everything is as opposite: that which is pointed out here, does not have a profound fundament" ${ }^{\prime 3}$. Empirical variety has led to forfeiting the fact that law does not subject to a sensitive learning and does not stem from materia, as material may only produce variety. Principles of unity and uniqueness as end goals of criminal law, are found outside material.

Thirdly, materia no longer reproduces the senses without which any law is deemed nonsense. In Aristoteles' view, "Materia is a material, or a material side of things, and for a thing to have a definition, i.e. obtain features defining it, it needs a form, something different from material, something non-material, which forms a certain thing out of uncertain materia" ${ }^{39}$. However, today we see a critical lack of forms, certainty, norms. This lacuna leads to a crisis of law, and the quest for the means of variety results only in its initial survival, as expressed by Chestnov I.L ${ }^{40}$.

Fourthly, contemporary approach of law scientists does not localize, but multiplies the problems of the legal domain, which inevitably influence the whole being of law and its microsphere. It is applicable in resolution

\footnotetext{
37 Pierre Bourdieu. (translation in russian) Prakticheskij smisl. Moscow, 2011, p.27.

38 Aristoteles. Metafizika. Translations into Russian, commentaries and interpretations/edited by Yeremeev S.I. Saint-Petersberg, Aleteja publishers, and Kiev, Elga publishers, 2002, p.50.

39 Ojzermann T.I. Metafilosofija. Teorija istoriko-filosofskogo processa. Moscow, 2009, p.322.

40 See Chestnov I.L. Sovremennie tipi pravoponimanija: fenomenologija, germenevtika, antropologija, sinergetika prava. SaintPetersberg, 2001.
} 
of particular criminal cases and useless for resolution of the noted issues of law. Here, as Revel J. noted, "reality is more complicated and not harmonious....if we change the scale of analysis, we shall see radically different landscapes" ${ }^{11}$. Also, it is not shown that "routine as itself, described in empirically given phenomenon, does not allow to see the real macroprocesses..." ${ }^{\prime 2}$, i.e. the being of law in general and criminal law in particular. In other words, the being does not allow to find a balance between arguments of the opposing sides and to apprehend its context of the living. The sphere of existence of the criminals is limited by their own "small world" ${ }^{43}$, in which the spiritual side as a source of world is not portrayed.

Fifth, "modern vision of the world has come to apprehension of a need to oppose the spiritual division of a man and the absurd of his existence a form of a positive movement of a free will" 44 . Routine existence can not influence it apriori. In the structures of the routineness, as believed by Russian researcher of law Popov E.A., there is no strict division between a value of a thing and a value of a spirit, which compose the fundament of criminal law. These structures prioritize not the human individuality, but things and the subject "for the real satisfaction" ${ }^{\text {". }}$. Thus, I suggest viewing the being of criminal law from viewpoint of the living of a man as a requested form and height in contrast to routineness, efficient for review of all subjects of this law and its subjects.

In conclusion, it is important to confess that little has been said here about the real and the living overall and the being of criminal law in particular, and little has been done to close up on the essential side of these categories. As referred to in the beginning of this article, the topic researched above was dedicated to apprehension of the relevancy of problems and related complications.

This has been made in a rather strange way, as it may seem. The research is void of claims and apriori narrativeness. The essence of this research lies in the

41 Revel J. Mikroistoricheskij analiz I konstruirovanie socialnogo//Odyssey. Moscow, 1996, p.119-120.

42 Chestnov I.L. Povsednevnost kak teoretiko-metodologicheskaya problema istoriko-yuridicheskoj nauki//Gorodsjaya povsednevnost v Rossii I na Zapade. Saratov, 2006, p.8.

43 Bachinin V.A. Antroposociologija I metafizika portreta// Chelovek, 2004, № 4, p.128.

44 Gorelov A.A., Gorelov T.A. "A man divided" and the idea of Unity//Chelovek, 2004, № 5, p.45.

45 Popov E.A. Zennostno-smislovoj rakurs struktur povsednevnosti//Filosofija I kultura, 2011, № 12 (48), p.30-31. notion and internal logic of categories of the being, which does not allow for much dwelling on its relevance. It proves its relevance by saying that being is the sphere of sense and non-being is the sphere of nonsense.

Critics may note that this thesis is not relevant for law, since it silences the "obligatory". Traditionally, the latter is viewed as an independent structure of the being, which presupposes law and other social regulators. However, at the very beginning of this research this category was irrelevant. The further narrative shall show the level of its relevance for the being. On preliminary stage it is sufficient to base all assumptions on the thesis formulated above (on being) and in its light to agree upon the fact that "the obligatory" should not be viewed as a structure which is autonomous within or outside the domain of the being. "The obligatory" is evaluated as an imminent quality of the being, which implements itself as a request for the correspondence of any event with with its sense. Otherwise it would transfer itself into the sphere of nonsense and nonbeing, or, in Hegel's wording, into the area of non-law ${ }^{46}$.

In general, at this point of research, the notion of the being is used for debating the surrounding problems and the evaluation of potential of thoughts that could possibly conquer it. The being is primarily used as a pretext for transferral on the level of recognition of thoughts on it. Here, the relevance of the issue is shown on example of conditionalities, which accompany researcher of philosophic and legal issues, and cast barriers to such research. The experience of these three thoughts highlights the doubts, which for a long time have caught the attention of law scientists and philosophers, who attempt learning the interdisciplinary dilemmas.

It was revealed that both philosophic and legal thoughts are seemingly self-efficient. Nothing shows panic in them. The architecture of these thoughts, as proven by its theorists, is ideal. One may definitely notice their simplicity. None of these by origin requires from any science of criminal law an ontological assessment of the results of its activity and neither it offers a true way that would provide an access of law to the sphere of sense. In many aspects these thoughts are self-centered. In Rortie R.'s opinion, they debate over linguistic matters rather than mental ones.

At this point, still, there is no solution to the issue of predominance in learning philosophic and legal issues. Many views are introduced. Some researcher ask a question like "Philosophy of law: philosophy or law

46 Hegel G.W.F. Filosofija prava. Moscow, 2007, p.143. 


\section{Bochkarev S.A.}

studies?"47. others are absolutely sure in philosophy of law as being a gnoseologic branch of the comprehensive theory of law ${ }^{48}$. Third group insists on the existence of purely philosophic problems that are attributed to the sphere of law. Fourth group evidence of a drama in a severe opposition between two philosophic positions in law, two polar "philosophies of law", that exist in the systems of social life and authority ${ }^{49}$. The fifth group of researchers searches for a compromise variant and offer grounds for "philosophy of law" However, their arguments are limited and common ground have already been found. It is a showcase that none of the noted thoughts, as concluded from a review of different positions, do not claim the predominance over a man and his community. Instincts of competition are found in these thoughts only at the level of research processes.

The case of the ontology of criminal law is quite similar. Philosophic thought shows itself in a way as if it incorporated the whole knowledge of the being and only reviews it in single cases of revanchism, as in case of Heidegger M. Criminal and legal thought demonstrates indifference the experience of philosophy. It recognizes that it does not know a pathway to the being. This thought previously has dealt without the notion of being and it is certain in that it possesses an opportunity to develop further in the world of social being without any knowledge of it.

In general, thoughts apprehend themselves and understand their self-sufficiency. The same is with the so called modern thought. Whatever its dreadful state, it remains a means of social linkage. Each of these thoughts finally constructs its own Babylon. Mutual misunderstanding is then referred to the imperfection of its nature or prejudices of its subjects. However the stumbling point is in the level of aloofness of thoughts from each other and from a man in general. They no longer weigh and counterbalance, but divide it. In their interpretation the subject seizes to possess its own being.

Under such circumstances, an aspiration to apprehend a man is a general one for both philosophic and legal thoughts, which as a meta-value can provoke them to reflect over social and to unite efforts in it. "Modern" thought is still very far from self-confidence. This virtue is unattainable without philosophic and legal thoughts. To achieve it, a philosophic and legal thought is needed to be a synergetic and complex action, which at all levels of being is able to form the life of a man with the help of reasonable and moral forms and alongside minimal influence of natural aspirations and affects.

\section{References:}

1. Kanke V.A. Filosofija. Moscow, 2000.

2. Ojzermann T.I., Ambivalentnost philosofii, Moscow, 2011.

3. Ojzermann T.I. Metaphilosophija. Teorija istoriko-filosofskogo processa, Moscow, 2009.

4. Matuzov N.I. Aktualnije problem teorii prava. Saratov, 2003.

5. Mur D. Principi etiki. Moscow, 1924.

6. Bochkarev S.A. Ideja ugolovnogo prava i yeyo filosofskoe iamerenije/Aktualnije problem rossijskogo prava, 2012, № 1.

7. Feuchtwanger L. Mudrost chudaka, ili smert I probrajhenije Jan-Jaka Rousseau. Moscow, 1965.

8. Berdiaev N.A. Sudba Rossii. Moscow, 1990.

9. Heidegger M. Bitie I vremya/translated from german by Bibikhina V.V. Moscow, Akademichesky prospect, 2011.

47 Chukin S.G. Pluralism, solidarnost spravedlisvost. K problem identichnost filosofsko-pravovogo diskursa v situatsii postmoderna. Saint-Petersberg, 2000.

48 See Kerimov D.A. Metodologija prava: predmet, funktsii, problem filosofii prava. Edition 5th, Moscow, 2009 Chukin S.G. Pluralism, solidarnost spravedlisvost. K problem identichnost filosofsko-pravovogo diskursa v situatsii postmoderna. SaintPetersberg, 2000.

49 See Alekseev S.S. Filosofija prava. Moscow, NORMA publishers, 1998.

50 Zakomlistov A.F. Juridicheskaya filosofija. Saint-Petersberg, 2003. 


\section{Law}

10. Berman G.G. Zapadnaya tradicija prava: epokha formirovanija. Moscow, 1994.

11. Korkunov N.M. Istorija filosofii prava. 7th Edition, Moscow, Krasand Publishers, 2011.

12. Permiakov Y.E. Vozvrashenije k metafizike $\mathrm{v}$ nauchnom poznanii prava//Pravo I obschestvo $\mathrm{v}$ epokhu peremen, Moscow, 2008.

13. Chestnov I.L. Obsheje I osobennoje v prave//Gosudarstvo I pravo na rubejhe vekov. Saint-Petersberg, 2000.

14. Fromm E. Chelovek dlia sebya. Revolutsija nadejhdi. Imet ili bit (translated from english and german/Erich Fromm, Moscow, AST publishers, 2007).

15. Sartre J. - P. Bitie I nichto. Opit fenomenologicheskoj ontologii (translated from french)/Jean-Paul Sartre, Moscow, AST publishers: ASTREL, 2012.

16. Sellars R.W. The essentials of Philosophy. University of Michigan. The Macmillan Company. 1917.

17. Rauh F. Essai sur le fondement metaphysique de la morale. Paris, 1891.

18. Berman G.J. Zapadnaya tradicija prava: epokha formirovanija. Moscow, 1994.

19. Jhalinsky A.E. Ugolovnoe pravo v ojhidanii peremen: teoretiko-instrumentalnij analiz. Moscow, 2008.

20. Popper K. Normalnaya nauka I opasnosti, sviazannie s nej//Filosofija nauki, 1997, № 3.

21. Pierre Bourdieu. (translation in russian) Prakticheskij smisl. Moscow, 2011.

22. Aristoteles. Metafizika. Translations into Russian, commentaries and interpretations/edited by Yeremeev S.I. Saint-Petersberg, Aleteja publishers, and Kiev, Elga publishers, 2002.

23. Chestnov I.L. Sovremennie tipi pravoponimanija: fenomenologija, germenevtika, antropologija, sinergetika prava. Saint-Petersberg, 2001.

24. Bachinin V.A. Antroposociologija I metafizika portreta//Chelovek, 2004, № 4.

25. Gorelov A.A., Gorelov T.A. "A man divided" and the idea of Unity//Chelovek, 2004, № 5.

26. Popov E.A. Zennostno-smislovoj rakurs struktur povsednevnosti//Filosofija I kultura, 2011, № 12 (48).

27. Hegel G.W.F. Filosofija prava. Moscow, 2007.

28. Chukin S.G. Pluralism, solidarnost spravedlisvost. K problem identichnost filosofsko-pravovogo diskursa v situatsii postmoderna. Saint-Petersberg, 2000.

29. Kerimov D.A. Metodologija prava: predmet, funktsii, problem filosofii prava. Edition 5th, Moscow, 2009 Chukin S.G. Pluralism, solidarnost spravedlisvost. K problem identichnost filosofsko-pravovogo diskursa v situatsii postmoderna. Saint-Petersberg, 2000.

30. Alekseev S.S. Filosofija prava. Moscow, NORMA publishers, 1998.

31. Yu.M. Reznik The metaphysics of man: images of being // SENTENTIA. European Journal of Humanities and Social Sciences. - 2014. - 1. - C. 25-33. DOI: 10.7256/1339-3057.2014.1.10847.

32. Алпатов A.A. On interconnection between positive and natural law // Право и политика. - 2014. - 3. C. 278-283. DOI: 10.7256/1811-9018.2014.3.9680.

\section{References (transliterated):}

1. Kanke V.A. Filosofija. Moscow, 2000.

2. Ojzermann T.I., Ambivalentnost philosofii, Moscow, 2011.

3. Ojzermann T.I. Metaphilosophija. Teorija istoriko-filosofskogo processa, Moscow, 2009.

4. Matuzov N.I. Aktualnije problem teorii prava. Saratov, 2003.

5. Mur D. Principi etiki. Moscow, 1924.

6. Bochkarev S.A. Ideja ugolovnogo prava i yeyo filosofskoe iamerenije/Aktualnije problem rossijskogo prava, 2012, № 1 .

7. Feuchtwanger L. Mudrost chudaka, ili smert I probrajhenije Jan-Jaka Rousseau. Moscow, 1965.

8. Berdiaev N.A. Sudba Rossii. Moscow, 1990.

9. Heidegger M. Bitie I vremya/translated from german by Bibikhina V.V. Moscow, Akademichesky prospect, 2011.

10. Berman G.G. Zapadnaya tradicija prava: epokha formirovanija. Moscow, 1994.

11. Korkunov N.M. Istorija filosofii prava. 7th Edition, Moscow, Krasand Publishers, 2011.

12. Permiakov Y.E. Vozvrashenije k metafizike v nauchnom poznanii prava//Pravo I obschestvo v epokhu peremen, Moscow, 2008.

13. Chestnov I.L. Obsheje I osobennoje v prave//Gosudarstvo I pravo na rubejhe vekov. Saint-Petersberg, 2000. 


\section{Bochkarev S.A.}

14. Fromm E. Chelovek dlia sebya. Revolutsija nadejhdi. Imet ili bit (translated from english and german/Erich Fromm, Moscow, AST publishers, 2007).

15. Sartre J. - P. Bitie I nichto. Opit fenomenologicheskoj ontologii (translated from french)/Jean-Paul Sartre, Moscow, AST publishers: ASTREL, 2012.

16. Sellars R.W. The essentials of Philosophy. University of Michigan. The Macmillan Company. 1917.

17. Rauh F. Essai sur le fondement metaphysique de la morale. Paris, 1891.

18. Berman G.J. Zapadnaya tradicija prava: epokha formirovanija. Moscow, 1994.

19. Jhalinsky A.E. Ugolovnoe pravo v ojhidanii peremen: teoretiko-instrumentalnij analiz. Moscow, 2008.

20. Popper K. Normalnaya nauka I opasnosti, sviazannie s nej//Filosofija nauki, 1997, № 3.

21. Pierre Bourdieu. (translation in russian) Prakticheskij smisl. Moscow, 2011.

22. Aristoteles. Metafizika. Translations into Russian, commentaries and interpretations/edited by Yeremeev S.I. Saint-Petersberg, Aleteja publishers, and Kiev, Elga publishers, 2002.

23. Chestnov I.L. Sovremennie tipi pravoponimanija: fenomenologija, germenevtika, antropologija, sinergetika prava. Saint-Petersberg, 2001.

24. Bachinin V.A. Antroposociologija I metafizika portreta//Chelovek, 2004, № 4.

25. Gorelov A.A., Gorelov T.A. “A man divided” and the idea of Unity//Chelovek, 2004, № 5.

26. Popov E.A. Zennostno-smislovoj rakurs struktur povsednevnosti//Filosofija I kultura, 2011, № 12 (48).

27. Hegel G.W.F. Filosofija prava. Moscow, 2007.

28. Chukin S.G. Pluralism, solidarnost spravedlisvost. K problem identichnost filosofsko-pravovogo diskursa v situatsii postmoderna. Saint-Petersberg, 2000.

29. Kerimov D.A. Metodologija prava: predmet, funktsii, problem filosofii prava. Edition 5th, Moscow, 2009 Chukin S.G. Pluralism, solidarnost spravedlisvost. K problem identichnost filosofsko-pravovogo diskursa v situatsii postmoderna. Saint-Petersberg, 2000.

30. Alekseev S.S. Filosofija prava. Moscow, NORMA publishers, 1998.

31. Yu.M. Reznik The metaphysics of man: images of being // SENTENTIA. European Journal of Humanities and Social Sciences. - 2014. - 1. - C. 25-33. DOI: 10.7256/1339-3057.2014.1.10847.

32. Alpatov A.A. On interconnection between positive and natural law // Pravo i politika. - 2014. - 3. - C. 278-283. DOI: 10.7256/1811-9018.2014.3.9680. 